Viso - Cadernos de estética aplicada Revista eletrônica de estética

ISSN 1981-4062

$N^{\circ} 3$, set-dez/2007

http://www.revistaviso.com.br/
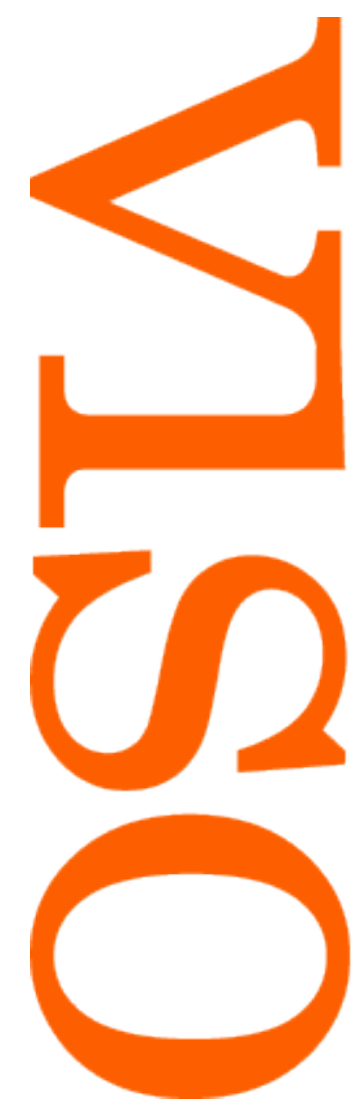

\title{
Beleza, amor e contemplação: sobre a possibilidade de se pensar uma estética em Plotino
}

Emmanuel Victor Hugo Moraes 


\section{RESUMO}

\section{Beleza, amor e contemplação:}

\section{sobre a possibilidade de se pensar uma estética em Plotino}

Metafísica, Ética e Estética se confundem no pensamento de Plotino. O autor nos convida a uma conversão, a um exercício individual de transformação das atitudes e da maneira de olhar. Chama-nos a reaprendermos a ver e a enxergar em nós mesmos o princípio e fim de toda a realidade, o Uno.

A beleza é o aguilhão que desperta em nós o amor e nos permite, através de uma ascese, termos um encontro místico, inefável e silencioso, no qual deixamos de lado até o próprio pensamento e nos abrimos à presença e ao super-derramamento de Amor do Uno, simples e primeiro. Fazer-se artista, esculpir a própria estátua, a própria alma, eis o resumo do convite plotiniano.

\section{Palavras-chave:}

Plotino - Metafísica - Estética - Ética - Amor - Beleza - Contemplação

\section{ABSTRACT}

Beauty, love and contemplation:

about the possibility of aesthetics in Plotinus

Metaphysics, Ethics and Aesthetics are confused in Plotinus thinking. The author invites us to a conversion, to an individual exercise of transformation of our attitudes and points of view. He makes us learn to watch and to see in ourselves the begining and the end of all reality: The One.

The beauty is the ferret that arouses love in ourselves and allows us, through an ascent, a mystic and silent encounter, in which we leave behind even thinking itself and open ourselves to the presence and the super-spillage of Love of The One, simple and eternal. To carve our own statue, our own soul - that is the summary of Plotinus' invitation.

\section{Keywords:}

Plotinus - Metaphysics - Aesthetics - Ethics - Love - Beauty - Contemplation 


\section{MORAES, E. V. H. "Beleza, amor e contemplação: sobre a possibilidade de se pensar uma estética em Plotino". In: Viso: Cadernos de estética aplicada, v. I, n. 3 (set-dez/2007), pp. 1-17.}

DOI: $10.22409 / 1981-4062 / \mathrm{V} 3 / / 43$

Aprovado: 12.09.2007. Publicado: 27.12.2007.

(C) 2007 Emmanuel Victor Hugo Moraes. Esse documento é distribuído nos termos da licença Creative Commons Atribuição-NãoComercial 4.0 Internacional (CC-BY-NC), que permite, exceto para fins comerciais, copiar e redistribuir o material em qualquer formato ou meio, bem como remixá-lo, transformá-lo ou criar a partir dele, desde que seja dado o devido crédito e indicada a licença sob a qual ele foi originalmente publicado. Licença: http://creativecommons.org/licenses/by-nc/4.0/deed.pt_BR

Accepted: 12.09.2007. Publicado: 27.12.2007.

(C) 2007 Emmanuel Victor Hugo Moraes. This document is distributed under the terms of a Creative Commons Attribution-NonCommercial 4.0 International license (CC-BYNC) which allows, except for commercial purposes, to copy and redistribute the material in any medium or format and to remix, transform, and build upon the material, provided the original work is properly cited and states its license.

License: http://creativecommons.org/licenses/by-nc/4.0/ 


\section{Convite}

Conhece-te a ti mesmo, ó Sócrates! Torna-te belo, Plotino! A nosso ver, essa é a definição da filosofia plotiniana: tornar-se belo é conhecer a si mesmo.

Tornar-se, eis o verbo que nos guia nesse texto. Junto a tantos outros, é o tornar-se que nos mostra o sentido real do projeto de Plotino, que, longe de um pensamento descritivo, faz uma exortação, um convite. Conclama-nos a sermos artistas de nós mesmos, esculpindo-nos e revelando-nos belos. Chama-nos a experimentar uma nova maneira de olhar e, por meio dela, perceber uma luz que se revela amor, um raio luminoso, que perpassa a alma e nos enche de alegria e nos permite um encontro com o inefável.

Encontro inefável, Uno inefável. O não dizer faz de Plotino um filósofo místico. O silêncio revela sua teoria. Suas aulas e suas Enéadas revelam o escultor que, dito metafísico, é o cantor do ex-tase silencioso, de um movimento de interiorização, que se pinta no sair de si, entrar em si, subida erótica, visão do divino.

Ele mesmo se diz não mais que um exegeta dos filósofos antigos, especialmente de Platão. Sua humildade disfarça sua filosofia. Há algo de próprio nela. Algo de único nele. Preferimos não concordar com a maioria dos comentadores que afirmam que o Parmênides e o Timeu platônicos são os grandes norteadores do pensamento do licopolitano. Preferimos pensar que, na verdade, é o Banquete que o guia. O Eros filosófico, o amante do belo, o mestre amado, o discípulo amante. $\mathrm{O}$ amor parece ser o grande tema de Plotino. O Uno, fonte de toda a vida, de todo o mundo, superabundância, é derramamento de amor. O Próprio Uno é "amor, amor e amor de si". ${ }^{1}$ Como ele mesmo nos diz, quem experimentou esse amor, quem pôde contemplar o Uno e se fazer um só com ele, sabe o que isso significa.

A pergunta então é: como experimentar esse amor? Como chegar ao Uno primordial? Torna-te belo!, responde Plotino. E com isso dá à beleza uma função específica: conduzir-nos para o alto, em direção ao fundamento metafísico do mundo, em direção ao Bem, despertando-nos o amor, através da contemplação.

Beleza, amor, contemplação. Esses são os conceitos que devemos analisar, as causas que nos motivam, o caminho que devemos trilhar. Sair de si mesmo, entrar em si mesmo, para o alto e para dentro, a partir da visão, contemplação erótica do Belo, em silêncio.

Anabagé: esta é a palavra-estrada, a topografia do belo e do movimento de tornar-se belo: para o alto e para dentro. 


\section{Beleza}

Iniciemos, pois, nossa caminhada. Com Plotino, pensemos o que é essa Beleza e a função que a ela foi dada. Para isso, utilizar-nos-emos especialmente daqueles tratados que podemos chamar de "textos estéticos" do filósofo neoplatônico: Enéada I.6 (1) Sobre a beleza; Enéada V.8 (31) - Sobre a beleza inteligível; Enéada VI.7 (38) - Sobre as idéias e Sobre o Bem; e Enéada VI.9 (9) - Sobre o Bem ou o Uno, dentre outros.

Na espreita da afirmação platônica de que o Belo é a mais evidente das idéias, Plotino inicia sua teoria de ascensão ao supremo Bem, ao absoluto inefável a partir do belo sensível, já que é ele que nos permite recordar a existência de uma Beleza inteligível, que, por sua vez, é fruto de uma espécie de derramamento da autocontemplação do Uno - princípio e fim de toda realidade.

A teoria estóica da beleza, assentada sobre as categorias da ordem, da simetria e da definição, é superada, no neoplatonismo plotiniano, por uma nova teoria, que passa a considerar a beleza como valor metafísico. Ao rejeitar a definição tradicional da beleza, Plotino nega que ela seja resultado do mundo material e ainda que seja parâmetro para análise do mundo inteligível. Ao contrário, pertencendo a uma ordem essencialmente inteligível, da qual se origina o mundo sensível, a beleza faz-se "presente" nele. Por esta "presença" percebemos e podemos analisar o belo sensível e, a partir dele, chegar ao belo inteligível e, então, à origem de toda a Beleza.

Tomemos, pois, o belo sensível e iniciemos nossa caminhada, nossa subida, mostrando alguns argumentos pelos quais Plotino refuta aquela forma, até então vigente, de "estética grega".

Plotino argumenta que, primeiramente, caso a beleza fosse simetria, o simples não poderia ser belo; ele se manifestaria apenas nos objetos complexos. A luz, o som, uma cor particular não seriam belos, já que não possuem diversidade de partes. Em segundo lugar, sabendo que um múltiplo ordenado não é múltiplo e que um objeto, ou mesmo o próprio rosto, pode parecer ora mais, ora menos belo, tal beleza não se deveria à proporção, já que esta não se altera, ainda que a expressão possa variar. Em terceiro lugar, se a beleza dependesse do acordo entre as partes de um objeto, como uma coisa bruta poderia ser bela? Um quarto argumento refere-se ao fato de que aquelas categorias podem ser submetidas a objetos materiais e não a objetos espirituais, como a virtude ou o conhecimento. ${ }^{2}$ Um último ponto diz respeito ao fato de que um ser vivo não partícipe daquelas categorias (a simetria, em especial), por ser dotado de alma, é mais belo que uma obra de arte simétrica, já que o grau de distanciamento em relação ao Uno é menor naquele que é dotado de alma do que em uma representação artística. Em outras palavras, a beleza não pode ser simetria. Elas podem ser contíguas, visto que a simetria não é fonte de beleza, mas apenas uma forma de sua manifestação externa (material). 
O que seria então esta beleza (sensível)? Seria uma beleza concernente à própria matéria? Já dissemos que não. A matéria não é bela em si, mas é belo o espírito que nela se revela e que lhe in-forma. Segundo Plotino, "é algo que apenas se apresenta, se faz perceptível e move a alma a pronunciar seu verbo, como se intelectualmente se compenetrasse com ele. Há um reconhecimento, uma recepção e de certa maneira uma integração da alma com ele". ${ }^{3}$

É, portanto, como se o belo não fosse aparência, mas uma espécie de essência. Uma idéia, uma forma que adentra a matéria e Ihe dá (compartilha) beleza. Uma beleza que só pode ser contemplada pela alma a partir do reconhecimento de algo do mesmo gênero e da lembrança do que ela mesma (a alma) é. Visto que a alma pertence ao mundo inteligível, se ela é capaz de perceber o belo sensível, é porque este participa de uma beleza superior, isto é, inteligível. Logo, as belezas sensíveis não são mais que imagens, sombras que adentram na matéria e, ao se nos mostrar, nos comovem.

Esta comoção, no entanto, não nos deve prender à aparência sensível, à beleza material. Ela deve nos elevar rumo à origem desta beleza (sensível). Do contrário, seríamos como Narciso que, preso à admiração de sua própria beleza, toma-a como verdade e não consegue perceber que a realidade está em outro lugar. ${ }^{4}$ Outrossim, somos convidados a pensar como Ulisses, desejoso de voltar à pátria. Para Plotino, ele representa aqueles que sabem pôr em prática a abstração [aphairésis] das coisas do mundo cá de baixo, e simboliza os que não se deixam fascinar pela beleza aparente de Circe ou Calipso, mas querem retornar à própria casa, à origem, que é fonte de toda Beleza e realidade: ao Uno. ${ }^{5}$

Afastar-se do mundo material não significa abandonar o mundo sensível, mas partir dele rumo ao inteligível, já que a beleza daquele revela um atributo deste. ${ }^{6}$ Não significa necessariamente deixar de olhar as coisas materiais, antes, "mudar a visão corpórea [blépein] para outra, despertando uma faculdade a qual todos possuem, mas da qual poucos fazem uso".

Passemos, assim, àquelas belezas que não são percebidas sensivelmente, mas através de um "olho", que na verdade não é um canal sensorial e que permite à alma elevar-se e comover-se com os efeitos que esta beleza (inteligível) produz. Ao elevar-se das belezas físicas às que não são percebidas pelos sentidos, a alma se recorda de sua origem e essa lembrança faz com que ela se perceba bela, a fim de ser capaz de contemplar as belezas do alto, já que "não pode contemplar a beleza, se não se torna ela mesma bela".

E diante de objetos belos, em particular aqueles que não podem ser percebidos sensivelmente, tais como a virtude e a justiça, a alma experimenta sentimentos de admiração, comoção, deleite, estupor sereno. 
O aguilhão [oístron] do desejo é provocado pela beleza e nos abre a possibilidade de uma nova visão, de uma luz e de uma graça [cháris] que em breve serão como uma suprema visão do divino.

Vendo, pois, o belo nas coisas sensíveis e nas inteligíveis, a alma passa a contemplar a própria beleza inteligível. $E$ até aí já se terá dado um grande passo para o encontro com o Bem. Dizemos um grande passo porque a Beleza não é o fim de nossa caminhada: "o Belo é posterior ao Uno e provém do Uno, de igual maneira que a luz do dia provém toda ela do sol". 9

Nesse momento, Plotino excede a tradição grega que representa o divino como kalós kai agathós: o Belo abre a porta para o Bem. Existe, na filosofia plotiniana, uma transição e uma superação da identidade beleza-bem. A beleza estabelece o trânsito ao Bem, Uno inefável e informe, princípio e fim de beleza:

Certamente, se podes captar algo que desejas que seja sem figura nem forma, será o mais desejável e amável e o amor será sem medida. É que, neste caso, o amor não está limitado, como também não há limites para o Amado; o amor a ele será um amor infinito, ao ponto que sua beleza seja também diferente; será beleza sobre beleza [kállos hypér kállos]. Não sendo pois um ser, de que Beleza se trata? O gerador da Beleza deve ser algo que fascina. Potência, pois, de toda beleza, é esplendor de beleza que produz beleza; gera o belo e o faz mais belo pela superabundância de beleza que possui, de maneira que é princípio e fim de beleza. ${ }^{10}$

Retomando nossa tarefa, como galgar esse último degrau que separa a Beleza do Bem? O Uno-Bem é fonte do ser, do pensamento, da vida e também da beleza. Estes seus "filhos" se encontram justamente no nível de realidade no qual chegamos após uma longa caminhada. O que se quer agora é adentrar à casa pátria. Como? É preciso excluir toda e qualquer alteridade e converter o olhar mais uma vez, cessando até mesmo o pensamento:

O que nos conduz até Ele são as purificações, as virtudes e o adereço da alma e uma vez que pisamos o solo inteligível e permanecemos ali, banquetearemos dos manjares daquela mesa. Se se chega a ser ao mesmo tempo espectador e espetáculo... sendo ser, pensamento e vivente total, não se contempla já ao Bem como algo externo. Mas transformado nele, já está próximo da meta: o seguinte é o Bem e o Bem está próximo, banhando de esplendor o universo inteligível. Nesta hora, despedido todo ensinamento, conduzido até aqui e instalado na Beleza, onde está, até aqui pensa, mas se levado pela onda de seu Intelecto se eleva por ela, vê de repente, não sabendo como; mas a visão, inundando seus olhos de luz, não faz que por mediação da luz se veja outra coisa, mas a luz mesma era o objeto da visão. Porque no espectador não havia duas coisas: o objeto visto e sua própria luz, nem inteligência do inteligível, só uma Luminosidade que posteriormente engendra essas duas coisas e as deixa coexistir consigo mesma. Mas o espectador mesmo era pura Luminosidade engendradora de inteligência, sem extinguir um pequeno raio de si mesma, permanecendo ela mesma, mas dando origem à inteligência, por ser quem era. Porque se não fosse tal qual era, a inteligência não teria vindo à existência. ${ }^{11}$ 
É que o transbordamento do Uno é o mais digno de ser amado. Sua Luz é a fonte com a qual se deseja ser pura luminosidade. Este desejo é que gera a Inteligência. Olhar e desejar aquele que é "amor de si" fazem vir à existência o pensamento, o ser, a vida e a beleza. Porque o estado mais amável é receber do Outro sua luz e resplendor e se fazer Luz com Ele.

Segundo Plotino, o Intelecto [noûs] gerado pelo excesso de luz do Uno-Bem possui, certamente, a faculdade de pensar. Mas, antes de tal faculdade, é dotado de uma outra, com a qual olha o que está pra além dele e, nessa contemplação alegre, se torna amante, embriagado de néctar, em completo bem-estar.

É assim que entraremos no Santuário: depois de trilhar uma escala da beleza, abandonaremos o pensamento e nos tornaremos Inteligência amante [noûs erón] e, ébrios do néctar divino, estaremos sós com o Só. ${ }^{12}$

\section{Amor}

Como todas as coisas foram embelezadas por aquele que é anterior a elas e dele receberam sua luz, a Inteligência recebeu dele o resplendor de sua atividade intelectiva com a qual irradiou sua própria natureza, e a alma recebeu dele força para viver uma vida mais copiosa. Assim, pois, a Inteligência alçou vôo até ele e lá ficou, feliz de estar ao seu redor. Também a alma que pôde se voltar até ele e conhecê-lo e contemplá-lo, desfrutou do espetáculo e ficou estupefata à medida em que era capaz de contemplar. Contemplou como atônita, se deu conta de que levava consigo algo dele e entrou em estado de nostalgia como os que com o retrato do ser querido se sentem movidos ao desejo de ver seu amado em pessoa. Mas do mesmo modo que os amantes daqui se configuram à semelhança de seus amados, realçando o aspecto de seus corpos e adequando suas almas à semelhança com os amados, e poderão se unir a eles, assim também a alma está cheia daquele e movida pelo amor desde o princípio. ${ }^{13}$

Duas vezes referimo-nos em nosso texto à expresão "erásmion kai eros o autós kai autoû eros", tentando definir, como Plotino, o Uno. A tradução que mais encontramos para o texto grego no diz: amor, amor e amor de si. Mas o próprio Plotino é enfático ao dizer que o Uno é Inefável. Não se pode dizer nada sobre ele, tudo que dele afirmamos é uma tentativa de Ihe atribuir predicados. A questão é que, por ser simples, anterior a tudo e em si mesmo, não lhe cabem predicados. Nem mesmo podemos dizer que ele é, até mesmo chamá-lo de Uno é afastar-se dele. Fazemos isso para que, justamente, tenhamos em vista aquilo que buscamos.

Nosso autor nos diz como filosofar, então, acerca do Uno:

O Uno é o que indubitavelmente buscamos e nessa busca examinamos o princípio de todas as coisas, isto é, o Bem e o que é primeiro; não convém que nos afastemos daqueles objetos que são seus vizinhos, caindo, por exemplo, nos que estão ao final da série. Muito ao contrário, temos de nos levantar a nós mesmos desde as coisas sensíveis, que são as últimas na escala dos seres, para ficarmos com Ele, livres de todo mal. Como queremos tender ao Bem, temos que ascender até o princípio, até chegar a 
fazermos-nos um só com ele no lugar da multiplicidade, se é que ambicionamos a contemplação do princípio e do Uno. Necessitamos certamente converter-nos em Inteligência e confiar a alma à Inteligência como se ela fosse seu descanso; assim poderá a alma sair de seu sonho e receber o que a Inteligência vê, pois é claro que a alma contemplará o Uno por meio da Inteligência, sem acrescentar, por sua parte, sensação alguma, nem nada que provenha da sensação. O que realmente é mais puro há de contemplá-lo a alma pela pura inteligência e pelo que há de primeiro nela. ${ }^{14}$

Partindo das coisas sensíveis, a alma deverá se recordar de sua divindade e, a partir daí, converter-se em Inteligência, contemplando a própria Beleza. Convertida em Inteligência, a alma cessará suas atividades e "repetirá" o primeiro ato da inteligência, que, por sua vez, é anterior ao próprio pensamento. Que ato é este? O olhar amoroso que, dirigido ao Princípio, produz o mundo inteligível - o ser, o pensamento, a vida e a beleza. Esse olhar amoroso só é possível porque o Uno carrega em si uma superabundância de amor. Traduzindo livremente aquela expressão grega, diríamos "Encantador e desejo ardente e de si mesmo, amor". Encantador porque é kállos hypér kállos. Mas como explicar o fato de ser desejo ardente e de si mesmo objeto de amor, se o Uno não tem necessidade nem de si mesmo, nem de nenhuma outra coisa?

Ama-se porque, apesar de seu transbordamento, jamais se diminui, jamais sai do santuário. Nisso consiste sua infinitude: amando-se eternamente, transborda-se e se faz desejo. Desejo não para si mesmo, mas para tudo o que dele provém. Sua doação inicia uma série para a qual também é fim. O Uno é princípio de tudo e todas as coisas desejam retornar a ele, porque há, nele, Amor. Afirmar, neste momento, que o Uno é amor seria bastante precipitado, já que Plotino, em um tratado dedicado a este tema, refere-se a vários tipos ou formas de amor: um que é sentimento, outro que é um deus e um terceiro que é um daimon. É o que analisaremos agora.

No que diz respeito ao amor como sentimento, "seguramente ninguém ignora que ele se origina nas almas quando desejam abraçar-se com alguma beleza, e que este desejo é de duas classes: um que nasce nos homens castos que se familiarizam com a beleza mesma, e o outro que tende a desembocar na realização de algum ato torpe". ${ }^{15}$

Aquele amor que nasce nos homens castos é um amor puro. Um amor que se volta para o Belo e para o Bem. É um amor que se divide em dois grupos: o primeiro é o daqueles que se elevam da beleza sensível à inteligível. É o amor que vem acompanhado da reminiscência da Beleza transcendente. $O$ outro pertence aos que não alcançaram a reminiscência daquela beleza celeste e a beleza daqui debaixo lhes aparece como verdadeira porque não se dão conta de que o sentimento amoroso tem sua origem na afinidade da Alma com a Beleza transcendente.

Por outro lado, já falando de um amor misto, aos homens que não são castos, o amor pode ser conforme ou contrário à natureza, em função da união carnal e de todos os outros atos que levam ao afastamento/esquecimento de Deus. 
Segundo Plotino, os que se unem o fazem porque desejam procriar no Belo. ${ }^{16}$ No entanto, assim como aqueles que agem de forma contrária à natureza e desconhecem a meta do amor, estes também podem cair em pecado [hamartía], fazendo com que o amor não seja mais do que uma paixão desregrada da carne, e assim, "sucumbem e se prostram sem conhecer nem a meta a que os conduzia o amor, nem o instinto de procriação, nem a função da imagem da beleza e muito menos a Beleza em si". ${ }^{17}$

Quando vem falar do amor como deus, "Plotino concebe a gênesis do amor em duas fases: na primeira como resultado do enamoramento da Alma suprema (pelo Espírito), o amor nasce como um olho, mas um olho que, todavia, ainda não vê em ato; na segunda, como resultado da visão da Alma, o amor nasce como um olho que vê em ato, como uma visão imagética". ${ }^{18}$

Plotino acredita que o amor seja uma realidade substancial e um intermediário, assim como um olho, entre a Alma suprema e o Espírito. Em outras palavras, a Alma suprema centraliza suas atividades no Espírito e se assemelha a ele. Nesse assemelhar-se, ela se enamora por ele e engendra o amor.

Este amor engendrado pela Alma suprema torna-se seu olho, pelo qual ela contempla aquele do qual ela mesma veio. Por isso o amor é um intermediário e um deus:

A alma vivia contemplando, e contemplando intensamente aquele que era Substância primeira. E esta era o objeto primário da visão da Alma; a Alma o mirava como seu próprio bem e se recreava nessa contemplação. E o objeto de sua visão era de tal natureza que o sujeito contemplante não podia fazer de sua contemplação uma ocupação marginal, de modo que, em virtude da intensidade da sua contemplação, a Alma engendrou de si mesma algo digno dela e do objeto de sua contemplação. Assim, desse sujeito ativo (a Alma) intensamente voltado para o objeto de sua visão, nasceu o amor. ${ }^{19}$

Emanado do encontro da contemplação com o objeto contemplado, o amor é comparado a um olho pleno do que vê, a uma visão que tem em si a sua imagem. É daí que Plotino levanta a hipótese de que o nome do amor [eros] tenha sido produzido pelo ato da visão [hórasis].

O interessante é que, a partir de uma suposição, esta relação ganha consistência no pensamento plotiniano, à medida que se sustenta a tese de que é necessário mudar a maneira de olhar, passando-se de um olhar sensível à pura contemplação. $O$ autor aponta também para uma escala erótica ascendente: primeiro, um olhar sensível [blépo] correspondendo a um amor sensível e humano; depois, um olhar mais íntimo [horáo], que permite à alma elevar-se até o inteligível e contemplar a própria beleza; por último, um olhar que é contemplação [theoría] do próprio Uno, fonte de toda a beleza, em um encontro amoroso místico e inefável, representado verbalmente somente se comparado ao prazer que sentem amante e amado. 
Observamos aqui o vocabulário do amor humano e sexual usado por Plotino, a nosso ver, como função imagética para descrever a experiência erótica inefável do Uno.

Ainda que nos chame a uma aphaíresis, a um afastamento do mundo sensível, é a representação do amor sensível que nos permite falar do amor místico, o que nos dá a entender que o amor humano é, de certa forma, indispensável, sendo portanto uma primeira forma, um primeiro degrau a subir, quando se pretende um amor verdadeiro: fazer de dois um só, o encontro com a fonte da Beleza, a união mística com o Uno.

Dirijamos nossas atenções nesse momento ao amor tido como daimon.

Eros, enquanto o amor da parte superior da Alma, é considerado como deus. No entanto, dada a existência de uma Alma inferior, ou melhor, de almas particulares, é necessário também que haja um amor ligado a elas. É o Eros chamado de daimon. Esse daimon, segundo Plotino, é o responsável por guiar cada Alma particular até a natureza do Bem: "Toda Alma, efetivamente, aspira ao Bem, ainda que seja uma Alma mesclada e convertida em Alma particular". ${ }^{20}$

Da mesma maneira que a Alma universal tem um amor universal, um amor que é um Deus, um amor puro e totalmente voltado para o divino, cada alma particular tem um amor particular. Cada uma delas tem um daimon que as guia, e, pelo fato de esse daimon representar um amor misto, cabe à Alma conhecer a meta do amor e, a partir daí, se elevar do mundo sensível ao inteligível.

Em resumo, o amor da Alma superior é um deus, um deus que mantém a Alma em perpétuo contato com o Bem, enquanto o amor da Alma particular é um daimon, um amor que conduz cada Alma até ele (ao Bem). ${ }^{21}$

Aparece-nos aqui uma outra questão: o fato de que este daimon não é somente amor. Plotino, referindo-se ao discurso da sacerdotisa de Mantinéia ${ }^{22}$, nos aponta a existência de vários daimones: o amor é apenas um deles.

Questionando a opinião platônica apresentada no mito do nascimento de Eros, Plotino retoma o Banquete, a fim de investigar se Pênia e Poros são os progenitores adequados para este daimon chamado Eros. ${ }^{23}$

De acordo com Platão, o amor-demônio gerado por Poros (recurso) e Pênia (pobreza) está ligado às noções de falta ou necessidade. Eros é filho de um pai engenhoso e de uma mãe mendicante, por isso nunca está saciado. Jamais poderá alcançar a plenitude enquanto levar a indeterminação na sua própria natureza.

É sabido, por outro lado, que na teoria da "processão" plotiniana a Alma do mundo é responsável por produzir o mundo sensível. No entanto, a Alma do mundo não é afetada pelo corpóreo: ela tem uma relação com o material, mas não desce ao material: é a 
matéria, o corpo que se prendem a ela e são por ela irradiados. Pênia, ao invadir o jardim de Zeus e se deitar ao lado de Poros, embriagado de néctar, concebe-lhe um filho: Eros, um amor-demônio, misto de divindade e de indigência. Eis aí a relação que Hadot julga poder ser estabelecida: "esse daimon, esse Eros nasce da união de Pênia e Poros e esta união simboliza a participação da Alma inferior, concebida a modo de matéria indeterminada, no logos daquela Alma superior, concebido como forma". ${ }^{24}$

Por um lado, o amor participa da indigência e por outro da abundância, de um a matéria, de outro a Inteligência, pois se algo é totalmente impartícipe do Bem, jamais buscará o Bem. Até mesmo Pobreza, desejosa de estar no Olimpo, sobe ao jardim de Zeus para mendigar e concebe Eros. Nasce então o amor. Nasce da aspiração da Alma (Pênia) pelo superior (Poros) e pelo Bem. ${ }^{25}$

Se de alguma forma podemos, a partir das comparações utilizadas, afirmar que esse Eros é filho de Poros e Pênia, não podemos mais por outro lado associá-lo aos conceitos de indigência ou necessidade no contexto plotiniano.

A nosso ver, estes termos devem ser substituídos por saudade, nostalgia. Pode-se dizer que, em Plotino, o próprio Uno é amor, é graça, é gratuidade sempre presente. É por isso que o amor e o desejo se abrem na sua presença: dele, que é amor, originam-se todas as coisas. E se ele é amor, de algum modo todas as coisas também o serão.

Desta forma, já não nos referimos a Eros como falta. Ao contrário, como nos diz Vernant, "Eros não equivale a nenhuma carência, mas, sim, à plenitude ou ao excesso de plenitude do Uno". ${ }^{26}$

Tanto é que, na união mística, a alma prova um sentimento de certeza, de bem estar, de alegria e de volúpia. É o retorno da alma à sua origem e à de todas as coisas. É o encontro do amante com o objeto amado, o gozo, a fusão do sujeito contemplante com o objeto contemplado, com o puro amor. E ainda mais:

\footnotetext{
Uma vez que a alma tenha tido a sorte de alcançá-lo, o Bem se faz presente, ou melhor, se manifesta presente nela quando ela se desinteressa das outras coisas, preparandose o mais formosa possível e assemelhando-se ao Bem, uma vez que a alma verá o Bem aparecendo de súbito dentro dela (nada se interpõe entre ela e o Uno: enquanto ele estiver presente, não poderá distingui-los. Eles não são mais dois, mas uma só coisa; imagem disso são os amantes daqui que desejam fundir-se com seus amados). A alma então não se dá conta de que está em um corpo, nem diz de si mesma que é alguma outra coisa: nem que é homem, nem animal, nem ser, nem ainda que é tudo; também não dispõe de tempo nem de vontade para essas coisas. Como era o Bem precisamente o que ela buscava, agora que o tem presente, vai ao seu encontro e se põe a olhá-lo em vez de olhar para si mesma. [...] Tudo quanto Ihe dava satisfação agora merece desprezo. Já não teme sofrimento algum enquanto está na sua presença, compenetrada na contemplação. ${ }^{27}$
} 
Em Plotino, "diferentemente" de Platão, mas ainda na sua trilha, Eros é um desejo ascensional que, muito mais que amor-desejo, se converte em saudade do Uno. Eros é o desejo que procura fazer coincidir o centro da alma com o centro do Uno, fazer coincidir amor com Amor. Eros é o próprio Uno. E também é a Alma tornada deus e semelhante ao Absoluto na sua subida, na sua conversão espiritual, na contemplação da sua origem.

Ao olhar para si mesma, não com os olhos físicos, mas com os olhos espirituais, a Alma será capaz de se recordar da sua origem. Primeiramente se lembrará de que faz parte de uma Alma divina, comum ao universo, livre de qualquer desmesura ou individuação. Pelo seu daimon se elevará até o amor dessa Alma (Suprema). Nesse ponto o seu amor já não será mais um daimon, mas um deus, pois a própria Alma se reconhecerá como divina e bela. $\mathrm{O}$ tornar-se finalmente será conjugado no pressente. A alma já não levará consigo os amores e paixões desse mundo, pois a saudade do Supremo arrebatará o seu peito. No silêncio, no mais íntimo do seu ser, a Alma poderá sair da "escuridão", poderá voltar a ver com os verdadeiros olhos.

Aqui, neste mundo, ainda que consciente do Amor divino, a Alma é como um cego dentro da luz. À medida que se esforça, purifica-se e trabalha sua espiritualidade, contudo, a Alma se coloca na possibilidade de ser invadida pela "presença sempre presente" do Bem.

Nessa caminhada, nessa vida espiritual, a Alma se embriagará do contato com o Bem, com a doçura divina. Compara-se tal doçura à própria luz. Uma luz que irradia, invade e ilumina tudo a seu redor. A luz é a origem do nosso olhar, de tal forma que, quando nos prontificamos a seguir o caminho de retorno ao Absoluto, o olhar de nossa Alma já não é mais um olhar mundano, mas um olhar que busca a claridade original. Será então um olhar amoroso que vê o Belo à luz do Bem e se funde com ele. Isso é a verdadeira vida, a mais sonhada virtude, a pura invasão do Supremo.

\section{Contemplação}

Apontamos em nosso texto, até o momento, duas escalas diferentes para ascensão ao Uno: uma que parte da beleza sensível para a beleza inteligível e desta para a fonte da beleza; outra que, partindo do amor humano, sensível e carnal, eleva a alma em uma escala erótica até o próprio amor.

Passaremos agora a uma questão que une e completa as duas temáticas precedentes: a contemplação.

"Toda a realidade, sensível ou inteligível, provém da contemplação e é contemplação, assim como todas as ações humanas são reflexo ou tentativa de contemplação" ${ }^{28}$ É contemplação se está voltada para o verdadeiro; tentativa de contemplação se é voltada para a imagem daquele que se deseja ver realmente. 
Contemplação exige silêncio, interiorização. Mais uma vez, trata-se de converter o olhar, transformando-o em uma visão legítima que preencha a alma.

O convite plotiniano ganha agora uma nova ênfase: agir de acordo com a contemplação e com a intensidade da contemplação. Conseqüentemente, produzir por impulso contemplativo, deixando de imitar o mundo das imagens e, pela contemplação, tentar reproduzir aqui o mundo divino.

Para Plotino, "todo produto é do mesmo gênero que seu produtor, ocupando, no entanto, um lugar inferior na escala hierárquica da constituição da realidade, já que a perfeição ontológica de um ser depende da perfeição da atividade de seu produtor". ${ }^{29}$

Da pura autocontemplação do Uno, surge um Intelecto, também divino, vizinho do Absoluto, mas hierarquicamente menor que ele. Do Intelecto à alma, da alma ao mundo. Tudo é produzido por contemplação. Logo, "contemplação é theoría. O resultado da contemplação, um theórema. Quanto mais perfeita a contemplação, mais perfeito o resultado da contemplação. Mesmo nas ações, é a intensidade da theoría que determina o resultado da ação, ou seu produto". ${ }^{30}$

Produzir algo se relaciona com a vontade de ver sensivelmente aquilo que foi idealizado. Neste sentido, tanto o agir quanto o produzir são uma forma de contemplação. E é pela contemplação que o homem pode retornar ao Uno. Inclusive nas suas ações e produções, que são formas de contemplação:

Os homens também, quando possuem uma contemplação enfraquecida, fazem da ação uma sombra da contemplação e do lógos. Isso porque a contemplação não basta para eles, pois sua alma é fraca, e eles não conseguem apreender suficientemente sua visão; por isso, como não são preenchidos por sua visão, mas desejam vê-la, eles são levados à ação para verem o que não podiam ver com o Intelecto. Quando produzem algo é que desejam vê-lo, e quando seu projeto, de acordo com suas possibilidades, torna-se ação, desejam que outros também o contemplem e percebam. Por toda parte iremos encontrar a produção e a ação que são a debilidade ou a conseqüência da contemplação: debilidade, se não tenciona nada além do praticado; conseqüência, se tem um outro objeto anterior para contemplar mais forte que o que foi produzido. Pois por que alguém, sendo capaz de contemplar o verdadeiro, vai, por iniciativa própria, voltar-se para a imagem do verdadeiro ${ }^{31}$

Contemplar é fazer-se transparente consigo mesmo. Pela contemplação podemos nos elevar ao mais íntimo de nós mesmos, ao verdadeiro. Convertemo-nos, por ela, em Intelecto. Já não seremos mais alma, pois, separando de nós todas as outras coisas, passaremos a ver por nós mesmos. Pensaremos na perspectiva da totalidade, não mais como indivíduo, mas como pensamento de totalidade, experimentando a concentração e a interioridade. Com isso, nosso Espírito se inflamará de amor e poderemos tocar, subitamente, o Uno. 
Beleza, amor, contemplação: a tarefa humana é agir e produzir pautando-se nesses princípios, de forma que o homem consiga caminhar por si mesmo. Ensinar o caminho é diferente de caminhar; indicamos a rota, mas é necessário desejar contemplar. Cala-se nosso autor. Fica aberta, pelo silêncio, a porta para o 'lugar sagrado'.

\section{5. "Estética"}

Falar em uma estética plotiniana não significa pensar regras para a apreciação de obras de arte, mas refletir metafisicamente sobe a capacidade humana de, mediante a beleza sensível, elevar-se ao absoluto.

Nessa metafísica neoplatônica, como vimos, não só a beleza, mas também o amor e a contemplação constituem aquilo que podemos chamar de projeto artístico plotiniano: tornar-se escultor de si mesmo.

Mudar a maneira de ver significa, inclusive no que se refere às artes propriamente ditas, partir do mundo sensível rumo ao fundamento de toda a realidade.

O que isso significa? Dissemos há pouco que tudo na alma é contemplação, mesmo as ações e produções. Não mais criticaremos as artes por serem imitações afastadas do real, mas, pela contemplação, nossa arte será também objeto a ser contemplado.

O artista não imita mais o mundo sensível, mas, enquanto 'consciente' da sua 'essência', poderá, pela contemplação e pelo seu desejo do absoluto, produzir por uma manifestação ou imitação do próprio inteligível: "pois mesmo Fídias não esculpiu [poiésas] sua estátua de Zeus à imagem de nenhum modelo sensível, mas tal como ele seria, se Zeus desejasse aparecer-nos diante dos olhos". ${ }^{32}$

Zeus representa aqui o próprio inteligível que pode nos aparecer diante dos olhos, quando convertemos nosso olhar em uma visão do divino, pura contemplação.

Antes mesmo de atribuirmos valor à questão artística, é o fazer-se artista de si mesmo que importa a Plotino. Sua filosofia é muito mais uma ética do que uma estética:

volta-te a ti mesmo e olha se tu não vês todavia a beleza em ti; faze como o escultor de uma estátua, que deve ser bela; toma uma parte, esculpe-a, pule-a e vai ensaiando até que tires linhas belas do mármore. Como aquele, tira o supérfluo, endireita o que é oblíquo, limpa o que está obscuro para torná-lo brilhante, e não cesses de esculpir tua própria estátua, até que o resplendor divino se manifeste, até que vejas a temperança sentada sobre um trono sagrado. ${ }^{33}$ 


\section{* Emmanuel Victor Hugo Moraes é mestrando em estética e filosofia da arte pela UFOP.}

1 PLOTINO, Enéada VI.8 [39] 15, 1 [As citações das Enéadas obedecem ao seguinte padrão: Enéada, tratado, ordem, posição cronológica, capítulo e linhas. Seguimos o texto editado e traduzido por FAGGIN, G.: PLOTINO, Enneadi, Milano: Bompiani, 2000.]

${ }^{2}$ Cf. PLOTINO, Enéada I.6 [1] 1

${ }^{3}$ PLOTINO, Enéada I.6 [1] 2, 4

${ }^{4}$ Cf. PLOTINO, Enéada I.6 [1] 8

${ }^{5}$ Cf. UllmanN, R. A. Plotino, um estudo das Enéadas. Porto Alegre: Edipucrs, 2002, p. 89.

${ }^{6}$ Cf. SANTOS, B.S. "Plotino: uma perspectiva neoplatônica da estética" In: BAUCHIWITZ, O. F. (org). O Neoplatonismo. Natal: Argos, 2001, p. 216.

${ }^{7}$ ULLMANN, R. A. Op. cit., p. 89.

${ }^{8}$ PLOTINO, Enéada I.6 [1] 9, 32

${ }^{9}$ PLOTINO, Enéada VI. 9 [9] 4, 10

${ }^{10}$ PLOTINO, Enéada VI.7 [38], 32, 24-34

${ }^{11}$ PLOTINO, Enéada VI.7 [38] 36, 9-29

${ }^{12}$ Cf. PLOTINO, Enéada VI,7 [38] 34, 1-7

${ }^{13}$ PLOTINO, Enéada VI.7[38] 31, 1-18.

${ }^{14}$ PLOTINO, Enéada VI.9 [9] 3,15-40

${ }^{15}$ PLOTINO, Enéada III.5[50]1

${ }^{16}$ PLOTINO, Enéada III.5[50]1

${ }^{17}$ PLOTINO, Enéada III.5[50]1

${ }^{18}$ HADOT. P. Plotin ou la simplicité du regard. Paris: Gallimard, 1997, p.126.

${ }^{19}$ PLOTINO, Enéada III.5[50]3

${ }^{20}$ PLOTINO, Enéada III.5[50]3

${ }^{21}$ PLOTINO, Enéada III.5[50]4

22 PLATÃO, Banquete, 203a

${ }^{23}$ PLOTINO, Enéada III.5[50]6

${ }^{24}$ HADOP, P. Op. cit., p. 134.

${ }^{25}$ PLOTINO, Enéada III.5[50] 9

${ }^{26}$ VERNANT, J-P. “Un, deus, trois, Eros”. In: LÉVÊQUE, P. Mélanges. Tome I: Religion. Paris: Belles Lettres, 1998, p. 235.

${ }^{27}$ PLOTINO, Enéada VI.7[38] 34

28 JUNIOR, J.C.B. "A legitimidade da arte na filosofia de Plotino". In:Calíope, 16. Rio de Janeiro: 2007, pp. $75 \mathrm{ff}$.

${ }^{29}$ Idem, p. 78.

${ }^{30}$ Idem, Ibidem.

${ }^{31}$ PLOTINO, Enéada, III.8 [30] 4, 31-47. Tradução de José Carlos Baracat Junior, apud JUNIOR, J.C.B. Op. cit., p. 76. 
${ }^{32}$ PLOTINO, Enéada V 8 [31] 1, 32-40 (grifo nosso). Tradução de José Carlos Baracat Junior, apud JUNIOR, J.C.B. Op. cit., p. 74.

${ }^{33}$ PLOTINO, Enéada I.6 [1] 9, 7-15. 